\title{
Validity and Reliability of Positive Youth Development Inventory Indonesian Version
}

\author{
Risma $^{1,2, *}$, Amung Ma'mun ${ }^{1}$, Berliana ${ }^{1}$, Nuryadi ${ }^{1}$ \\ ${ }^{1}$ Sport Education, School of Postgraduate Studies UPI, Setiabudi 229, Bandung, 40154, West Java, Indonesia \\ ${ }^{2}$ Faculty of Teacher Training and Education, Universitas Galuh, RE. Martadinata 150, Ciamis, 46274, West Java, Indonesia
}

Received August 22, 2021; Revised September 17, 2021; Accepted October 28, 2021

\begin{abstract}
Cite This Paper in the following Citation Styles
(a): [1] Risma, Amung Ma'mun, Berliana, Nuryadi, "Validity and Reliability of Positive Youth Development Inventory Indonesian Version," International Journal of Human Movement and Sports Sciences, Vol. 9, No. 6, pp. 1213 - 1218, 2021. DOI: 10.13189/saj.2021.090615.
\end{abstract}

(b): Risma, Amung Ma'mun, Berliana, Nuryadi (2021). Validity and Reliability of Positive Youth Development Inventory Indonesian Version. International Journal of Human Movement and Sports Sciences, 9(6), 1213 - 1218. DOI: 10.13189/saj.2021.090615.

Copyright $\odot 2021$ by authors, all rights reserved. Authors agree that this article remains permanently open access under the terms of the Creative Commons Attribution License 4.0 International License

\begin{abstract}
Positive Youth Development has become a hot topic of research in sports, physical education and physical activity. Positive Youth Development is a youth approach based on the belief that all young people have strengths and skills that can be developed when matched with the right resources. Positive Youth Development is a strengths-based perspective that focuses on developing skills and natural potential to promote healthy and adaptive development in young people. Positive Youth Development is one of the important factors in producing a superior generation. Therefore, it is necessary to have an instrument to measure Positive Youth Development. The article presents an analysis of the validity and reliability of the Positive Youth Development Inventory Indonesian version, which adopts from the original Positive Youth Development Inventory. Questionnaires are translated by linguists who have more than 10 years of experience. The number of appropriate question items is 53 out of a total of 55 question items, so the level of conformity is $96.3 \%$. The 2 question items should be corrected by the expert, until they were appropriate and legible by the expert. Validity test uses Pearson Product Moment and reliability test uses Cronbach's Alpha. The results of the validity test showed that 55 items had Sig. $<0.05$, so that 55 items are valid. The results of the reliability test with Cronbach's Alpha $=0.967>0.6$, so the instrument is reliable.
\end{abstract}

Keywords Indonesian Version, Positive Youth Development Inventory, Reliability, Validity

\section{Introduction}

Positive Youth Development (PYD) has become a topic in psychology and exercise research in recent years. PYD is an approach based on the child and adolescent development based on the assumption that all adolescents have the potential to gain positive development in various aspects [1]. PYD is a holistic view of development that refers to how children and adolescents experience optimal development through their involvement in organized activities [2]. Optimal development can be defined as a way that allows individuals to live healthy, satisfying, productive lives, as a generation that is expected to become individuals who can contribute to society, socialize and can participate in cultural activities and social interactions [3].

Sports, physical education and physical activity are considered capable of providing the optimal experience needed by children and adolescents, so it can be interpreted that sports, physical education and physical activity are related to PYD [2], [4]-[7]. PYD is becoming popular because it can increase positive growth in young people in the home, school and community environment, therefore PYD must become an empirically valid model which can be widely applied, including specific and measurable constructions.

PYD is the main framework for researchers and 
practitioners in the field of adolescent development. There is an urgent need to develop related PYD measurement instruments [8]. Bowers and colleague developed the Five C's model in PYD using Confirmatory Factor [9]. Sieng and colleague developed Five C's as the foundation for developing Five C's as the basic framework in PYD which is described in Table 1 [10].

Hence, the Positive Youth Development Sustainability Scale (PYDSS) developed by Sieng and colleague, a Positive Youth Development assessment tool that was developed from the Five C's of the PYD model which resulted in Contribution. PYDSS consists of 29 question items or statements developed from Six C's [10].

In addition to the PYDSS, the Positive Youth Development Inventory (PYDI) is also used to measure PYD. Arnold and colleague developed a Positive Youth Development Inventory, consisting of 55 items of questions or statements used to assess aspects of adolescent development before and after participating in educational programs or youth development programs [11]. The domains assessed by PYDI consist of Six C's namely Competence, Confidence, Character, Connection, Caring and Contribution. The target population used by PYDI is youth aged 10 and above.

The purpose of this article is to test the validity and reliability of the PYDI Indonesian version. The PYDI Indonesian version needs to be developed and tested for its validity and reliability considering that in Indonesia itself there are many studies in the fields of sports, physical education and physical activity. The PYD philosophy is in line with the national education philosophy, a philosophy that views the importance of youth character building which helps young people navigate adolescence in a healthy way by providing the basis for a series of attractive and promising programs for youth [12].

\section{Materials and Methods}

This article presents the results of the validity and reliability test of PYDI Indonesian version, adapted from original PYDI. The PYDI contains 55 items, developed by Arnold and colleague [11]. The PYDI consists of questions or statements consisting of indicators of Competence, Confidence, Character, Connection, Caring and Contribution. The questionnaire is a closed questionnaire using a rating scale of Strongly Disagree (1), Disagree (2), Agree (3) and Strongly Agree (4).

\subsection{Participant}

Participants in the of the PYDI Indonesian version validity and reliability test involved 68 participants. The age criteria of the participants are over 17 years old.

\subsection{Population \& Sample}

The research population is the first-year students of the Physical Education study program, Faculty of Teacher Training and Education Universitas Galuh.

\subsection{Instrument}

The instrument was adopted from the Positive Youth Development Inventory developed by Arnold, Nott \& Meinhold (2012).

\subsection{Procedure}

The English version of the PYDI was translated into Indonesian. To test the validity of the questionnaire construct, expert judgment analysis was used. The original PYDI instrument was translated by two experienced translators. The number of appropriate question items is 53 out of a total of 55 question items, so the level of conformity is $96.3 \%$. The 2 question items were corrected by the experts, until they were appropriate and legible by the experts. Then, the questionnaire was distributed through online media using Google Form and distributed to be filled out by the participants.

Table 1. Five C's Foundation Positive Youth Development

\begin{tabular}{ll}
\hline Characteristic & \multicolumn{1}{c}{ Definition } \\
\hline Competence & $\begin{array}{l}\text { Being able to act effectively in school, in social situations, and at work. Caplan et al (1992); Weissberg, Caplan and Sivo } \\
(1989) .\end{array}$ \\
\hline Confidence & Believing in one's self and ability. Fetterman, Kaftarian, and Wandersman (1996). \\
\hline Character & $\begin{array}{l}\text { Knowing what is right or wrong and how to do the right thing. Piaget (1952,1970); Kohlberg (1963,1969, 1970); } \\
\text { Hoffman (1981). }\end{array}$ \\
\hline Connection & $\begin{array}{l}\text { Working collaboratively with parents, peers, siblings, teachers, coaches, or other community members. Ainworth, } \\
\text { Blehar, Waters and Wall (1978); Bowbly (1973, 1979, 1982); Mahler, Bergman and Pine (1975). }\end{array}$ \\
\hline Caring & Having a sense of compassion or social justice. Salovey and Mayer (1990); Goleman (1995). \\
\hline
\end{tabular}




\subsection{Data Analysis}

The validity test is useful to determine the validity or suitability of the questionnaire used by researchers in measuring and obtaining research data from respondents [13]. For the validity of the questionnaire, the Pearson Product Moment validity test was carried out.

The reliability test aims to see whether the questionnaire has consistency if the measurement is carried out using a questionnaire is repeated [13]. The reliability test of the questionnaire was carried out with Cronbach Alpha.

\section{Result}

This article aims to test the validity and reliability of the PYDI Indonesian version. The first step is to translate it from English to Indonesian. The translation process involves two independent translators. The results of each translator are compared. The differences in the results are identified and then discussed until an agreement is found on the translation results of the two translators. The next step is to draft the PYDI Indonesian version. The draft version was reviewed and commented on by two researchers. After joint discussion, revisions were made based on these comments and the final version of the translated instrument was prepared. To check the legibility of the translation results, the draft was translated back into English and compared with the original version. In this step, there are no inconsistencies. The next step is to prepare the final draft of the PYDI Indonesian version.

The PYD variable was measured using PYDI using 55 questions or statements. PYDI Indonesian version score data from each participant was collected and analyzed. The Mean score for each domain from the PYDI Indonesian version is presented in Table 2.

Table 2. Domain Mean Score of PYDI Indonesian Version

\begin{tabular}{cc}
\hline Domain & Mean \\
\hline Competence & 46.19 \\
\hline Confidence & 29.03 \\
\hline Character & 29.43 \\
\hline Connection & 26.49 \\
\hline Caring & 25.94 \\
\hline Contribution & 22.50 \\
\hline
\end{tabular}

Based on the Pearson Product Moment validity test with Statistical Product and Service Solution (SPSS), the basis for taking is based on the Pearson validity test guidelines, namely looking at the value of Sig. the questionnaire item is declared valid if, Sig. $<0.05$ and declared valid if Sig. $>0.05$ [14]. The significance value of each item PYDI Indonesian version is presented in Table 3.

Based on Pearson Product Moment validity test result, value of Sig. 55 items $0.000<0.05,55$ items of the questionnaire are said to be valid. 
Table 3. Item's Significant (Two-tailed) Pearson Correlations

\begin{tabular}{|c|c|c|}
\hline $\mathbf{X}$ & Sig. & Result \\
\hline 1 & 0.000 & valid \\
\hline 2 & 0.000 & valid \\
\hline 3 & 0.000 & valid \\
\hline 4 & 0.000 & valid \\
\hline 5 & 0.000 & valid \\
\hline 6 & 0.000 & valid \\
\hline 7 & 0.000 & valid \\
\hline 8 & 0.000 & valid \\
\hline 9 & 0.000 & valid \\
\hline 10 & 0.000 & valid \\
\hline 11 & 0.000 & valid \\
\hline 12 & 0.004 & valid \\
\hline 13 & 0.000 & valid \\
\hline 14 & 0.000 & valid \\
\hline 15 & 0.000 & valid \\
\hline 16 & 0.000 & valid \\
\hline 17 & 0.000 & valid \\
\hline 18 & 0.000 & valid \\
\hline 19 & 0.000 & valid \\
\hline 20 & 0.000 & valid \\
\hline 21 & 0.000 & valid \\
\hline 22 & 0.000 & valid \\
\hline 23 & 0.000 & valid \\
\hline 24 & 0.000 & valid \\
\hline 25 & 0.000 & valid \\
\hline 26 & 0.000 & valid \\
\hline 27 & 0.000 & valid \\
\hline 28 & 0.000 & valid \\
\hline 29 & 0.000 & valid \\
\hline 30 & 0.000 & valid \\
\hline 31 & 0.000 & valid \\
\hline 32 & 0.000 & valid \\
\hline 33 & 0.000 & valid \\
\hline 34 & 0.000 & valid \\
\hline 35 & 0.000 & valid \\
\hline 36 & 0.000 & valid \\
\hline 37 & 0.000 & valid \\
\hline 38 & 0.000 & valid \\
\hline 39 & 0.000 & valid \\
\hline 40 & 0.000 & valid \\
\hline 41 & 0.000 & valid \\
\hline 42 & 0.000 & valid \\
\hline 43 & 0.000 & valid \\
\hline 44 & 0.000 & valid \\
\hline 45 & 0.000 & valid \\
\hline 46 & 0.000 & valid \\
\hline 47 & 0.000 & valid \\
\hline 48 & 0.000 & valid \\
\hline 49 & 0.000 & valid \\
\hline 50 & 0.000 & valid \\
\hline 51 & 0.000 & valid \\
\hline 52 & 0.000 & valid \\
\hline 53 & 0.000 & valid \\
\hline 54 & 0.000 & valid \\
\hline 55 & 0.000 & valid \\
\hline
\end{tabular}


Hence, 55 valid items were tested for reliability. The basis for making Cronbach's Alpha reliability decisions is done by looking at the output value of Cronbach's Alpha. The questionnaire is said to be reliable if Cronbach's Alpha $>0.6[14]$.

Table 4. Cronbach Alpha Reliability Test Output

\begin{tabular}{cc}
\hline \multicolumn{2}{c}{ Reliability Statistics } \\
\hline Cronbach's Alpha & N of Items \\
\hline .967 & 55 \\
\hline
\end{tabular}

Based on Table 4, the results of the reliability test showed that Cronbach's Alpha. It was known that the Cronbach's Alpha value was $0.967>0.6$, then the questionnaire was declared reliable. So it can be concluded that the PYDI Indonesian version can be called an instrument that has a high level of consistency in measuring the PYD variable.

Referring to the results of the validity and reliability test of the PYDI Indonesian version, the researchers can directly use the PYDI Indonesian version to measure PYD.

\section{Discussions}

This paper aims to test the validity and reliability of the PYDI Indonesian version. Many definitions of PYD emerge among researchers. Hamilton and colleague stated that optimal development of youth enables individuals to lead healthy, fulfilling, and productive lives as youth and later as adults as they acquire the competence to earn a living, to engage in civic activities, to care for others, and to participate in social relations and cultural activities [3]. Various PYD programs seek to improve the health, happiness and competence of adolescents by becoming productive and satisfied adults [15]. Effective PYD promotes social development and instils a sense of resilience among adolescent [16].

The PYD approach is built on the 5C approach: Competence, Confidence, Connection, Character, and Caring. Researchers believe that young people who have and incorporate these five characteristics into their lives will show the sixth character, namely contribution to themselves, their families, communities, and society. In addition, young people who in their lives do not implement these five characters are at higher risk of having problems including problems related to personal, social and behavior [17].

The model for classifying PYD results already exists, but one of the most well-known models is the Five C's. The Five C's model describes PYD results in five domains: Competence, Confidence, Connections, Character and Caring. Sieng and colleague developed the Five C's model into Six C's by adding contribution as the PYD result domain [10].
Competence, reflecting the development of multiple skills across specific domains such as health, physical and social (communication, conflict resolution, assertiveness and resistance) and cognitive domains [16]-[18]. Confidence refers to an increase in self-concept, self-efficacy and self-esteem [18]. Connection reflects youth's ability to develop, strengthen and maintain positive social relationships with family members, friends, and the community [19]. Character, knowing what right is and what wrong is and how to do the right thing [20]. Caring, reflecting compassion or social justice [21]. Contribution, appears from another PYD output [18].

The measurement of PYD is carried out to see the output of the PYD program, considering that PYD is an interesting research topic to study. Research on PYD in Indonesia is important to do so that the goals of national education can be realized, namely developing capabilities and shaping the character and civilization of a dignified nation to educate the nation's life, aiming to develop the potential of students to become human beings who believe and fear God Almighty, have a noble character, healthy, knowledgeable, capable, creative, independent and become democratic and responsible citizens [22].

\section{Conclusions}

The results of the validity analysis concluded that 55 items were valid to measure PYD. The reliability test on 55 items concluded that the instrument was reliable. Thus, the PYDI Indonesian version can be used by researchers to measure PYD. PYD is an approach based on the development of children and adolescents based on the assumption that all adolescents have the potential to obtain positive development in various aspects. PYD is one of the important variables because PYD can allow teenagers to have a good youth. PYD is a solution to various social problems among teenagers. If teenagers get the opportunity to develop optimally, it is hoped that when they grow up they can become individuals who have various skills that they can use in social life.

\section{Acknowledgements}

The authors would like to thank to head of study program of Physical Education Faculty of Teacher Training and Education, Universitas Galuh, Kuston Sultoni, Jajat, Febriana Pratiwi, Tika, and colleagues and reviewers for their valuable comments.

\section{REFERENCES}

[1] R. M. Lerner, J. B. Almerigi, C. Theokas, and J. V. Lerner, 
"Positive youth development: A view of the issues," $J$. Early Adolesc., vol. 25, no. 1, pp. 10-16, 2005, doi: $10.1177 / 0272431604273211$

[2] N. Holt and K. Neely, "Positive Youth Development Through Sport: A Review," Rev. Iberoam. Psicol. Del Ejerc. Y El Deport., vol. 6, no. 2, pp. 299-316, 2011.

[3] S. F. Hamilton, M. A. Hamilton, and K. Pittman, The Youth Development Handbook: Coming of Age in American Communities. Thousand Oaks: Sage Publications, 2004.

[4] J. A. Fredricks and S. D. Simpkins, "Promoting Positive Youth Development Through Organized After-School Activities: Taking a Closer Look at Participation of Ethnic Minority Youth," Child Dev. Perspect., vol. 6, no. 3, pp. 280-287, 2012, doi: 10.1111/j.1750-8606.2011.00206.x.

[5] M. A. Hemphill, "Positive Youth Development through Physical Activity: Opportunities for Physical Educators," Strategies, vol. 27, no. 4, pp. 39-41, 2014, doi: $10.1080 / 08924562.2014 .918460$.

[6] M. A. Hemphill, B. Gordon, P. M. Wright, M. A. Hemphill, B. Gordon, and P. M. Wright, "Sports as A Passport to Success: Life Skill Integration in A Positive Youth Development Program," Phys. Educ. Sport Pedagog., vol. 0, no. $0, \quad$ pp. 1-12, 2019, doi: 10.1080/17408989.2019.1606901.

[7] T. Forneris, M. A. Whitley, and B. Barker, "The Reality of Implementing Community-Based Sport and Physical Activity Programs to Enhance the Development of Underserved Youth: Challenges and Potential Strategies," Quest, vol. 65, no. 3, pp. 313-331, 2013, doi: $10.1080 / 00336297.2013 .773527$.

[8] K. Dukakis, R. London, and M. McLaughlin, "Positive Youth Development: Individual, Setting and System Level Indicators," Issue Br., 2009, [Online]. Available: http://www.thrivefoundation.org/wp-content/uploads/2014 /11/Positive-Youth-Development_Individual-Sett-ing-andSystem-Level-Indicators.pdf.

[9] E. P. Bowers, Y. Li, M. K. Kiely, A. Brittian, J. V. Lerner, and R. M. Lerner, "The Five Cs Model of Positive Youth Development: A Longitudinal Analysis of Confirmatory Factor Structure and Measurement Invariance," J. Youth Adolesc., vol. 39, no. 7, pp. 720-735, 2010, doi: 10.1007/s10964-010-9530-9.

[10] M. Sieng, S. Cloutier, and K. Irimata, "Positive Youth Development Sustainability Scale (PYDSS): The
Development of an Assessment Tool," J. Soc. Chang., vol. 10, no. 1, pp. 81-97, 2018, doi: 10.5590/josc.2018.10.1.07.

[11] J. . Arnold, M.E; Nott, B.D; Meinhold, Positive Youth Development Inventory. Corvalis: Oregon State University, 2012.

[12] J. L. Roth and J. Brooks-Gunn, "What Exactly is a Youth Development Program? Answers From Research and Practice," Appl. Dev. Sci., vol. 7, no. 2, pp. 94-111, 2003, doi: 10.1207/S1532480XADS0702_6.

[13] Hardani et al., Buku Metode Penelitian Kualitatif dan Kuantitatif, 1st ed. Yogyakarta: Pustaka Ilmu, 2020.

[14] I. Machali, Statistik Itu Mudah, Menggunakan SPSS Sebagai Alat Bantu Statistik. Yogyakarta: Lembaga Ladang Kata, 2015.

[15] M. R. Linver, J. L. Roth, and J. Brooks-Gunn, "Patterns of Adolescents' Participation in Organized Activities: Are Sports Best When Combined With Other Activities?," Dev. Psychol., vol. 45, no. 2, pp. 354-367, 2009, doi: $10.1037 / \mathrm{a} 0014133$.

[16] R. F. Catalano, M. L. Berglund, J. A. M. Ryan, H. S. Lonczak, and J. D. Hawkins, "Positive Youth Development in the United States: Research Findings on Evaluations of Positive Youth Development Programs," Ann. Am. Acad. Pol. Soc. Sci., vol. 591, no. January, pp. 98-124, 2004, doi: $10.1177 / 0002716203260102$.

[17] R. Lerner, "The Positive Development of Youth," Posit. Dev., vol. 4, pp. 1-8, 2005.

[18] R. D. Fuller, V. E. Percy, J. E. Bruening, and R. J. Cotrufo, "Positive Youth Development: Minority Male Participation in a Sport-Based Afterschool Program in an Urban Environment," Res. Q. Exerc. Sport, vol. 84, no. 4, pp. 469482, 2013, doi: 10.1080/02701367.2013.839025.

[19] M. S. Mahler, F. Pine, and A. Bergman, The Psychological Birth of The Human Infant Symbiosis and Individuation, 4th ed. London: Karnac ltd, 2002.

[20] J. Piaget, the Psychology of Intelligence. London: Routledge Taylor \& Francis Group, 2003.

[21] D. Goleman, Social Intelligence: The New Science of Human Relationships. United States of America: Bantam Dell, 2006.

[22] Undang Undang Republik Indonesia Nomor 20 Tahun 2003 Tentang Sistem Pendidikan Nasional. Indonesia, 2003. 